\title{
COMMONALITY AND PARTICULARITY IN ETHICS
}




\section{Commonality and Particularity in Ethics}

Edited by

Lilli Alanen

Department of Philosophy

University of Helsinki

Finland

Sara Heinämaa

Researcher

Academy of Finland

and

Thomas Wallgren

Research Assistant

Academy of Finland

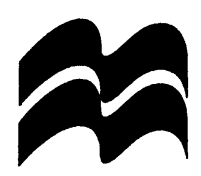


First published in Great Britain 1997 by

MACMILLAN PRESS LTD

Houndmills, Basingstoke, Hampshire RG21 6XS and London

Companies and representatives throughout the world

A catalogue record for this book is available from the British Library.

ISBN 978-1-349-25604-4 ISBN 978-1-349-25602-0 (eBook)

DOI 10.1007/978-1-349-25602-0

First published in the United States of America 1997 by

ST. MARTIN'S PRESS, INC.,

Scholarly and Reference Division,

175 Fifth Avenue, New York, N.Y. 10010

ISBN 978-0-312-17231-2

Library of Congress Cataloging-in-Publication Data

Commonality and particularity in ethics / edited by Lilli Alanen, Sara

Heinämaa, and Thomas Wallgren.

p. $\mathrm{cm}$.

Includes bibliographical references and index.

ISBN 978-0-312-17231-2 (cloth)

1. Ethics. I. Alanen, Lilli. II. Heinämaa, Sara, 1960 .

III. Wallgren, Thomas.

BJ1012.C59 1997

$170-$ dc 20

$96-43910$

CIP

Editorial matter and selection $\odot$ Lilli Alanen, Sara Heinämaa and Thomas Wallgren 1997 Text @ Macmillan Press Ltd 1997 except chapter 8 @ Peter Winch 1997

Softcover reprint of the hardcover 1st edition 1997

All rights reserved. No reproduction, copy or transmission of this publication may be made without written permission.

No paragraph of this publication may be reproduced, copied or transmitted save with written permission or in accordance with the provisions of the Copyright, Designs and Patents Act 1988, or under the terms of any licence permitting limited copying issued by the Copyright Licensing Agency, 90 Tottenham Court Road, London WIP 9HE.

Any person who does any unauthorised act in relation to this publication may be liable to criminal prosecution and civil claims for damages.

The authors have asserted their rights to be identified as the authors of this work in accordance with the Copyright, Designs and Patents Act 1988.

This book is printed on paper suitable for recycling and made from fully managed and sustained forest sources.

$\begin{array}{llllllllll}10 & 9 & 8 & 7 & 6 & 5 & 4 & 3 & 2 & 1\end{array}$

$\begin{array}{llllllllll}06 & 05 & 04 & 03 & 02 & 01 & 00 & 99 & 98 & 97\end{array}$ 


\section{Contents}

List of Contributors

vii

Lilli Alanen, Sara Heinämaa and Thomas Wallgren: Introduction

1 Annette C. Baier:

Doing Things With Others: The Mental

Commons

2 Frederick Stoutland:

Why are Philosophers of Action so Anti-Social?

45

3 Lars Hertzberg:

Voices of the Will

75

4 Olli Lagerspetz:

The Notion of Trust in Philosophical Psychology

95

5 Annette C. Baier:

Response to Olli Lagerspetz

6 Ilham Dilman:

Psychoanalysis and Ethics: Some Reflections on the Self in its Relationship to Good and Evil

7 D. Z. Phillips:

Ethics and Humanistic Ethics - A Reply to

Dilman

8 Peter Winch:

Professor Anscombe's Moral Philosophy

9 Cora Diamond:

Moral Differences and Distances: Some Questions 197

10 Raimond Gaita:

The Moralization of Good and Evil

11 Sören Stenlund:

Ethics, Philosophy and Language 
12 Thomas Wallgren:

Varieties of Enlightenment Optimism: Discourse Ethics and Wittgensteinian Particularism in Conversation

13 Morten Raffnsøe-Møller:

Moral Reasoning and Moral Practice

14 Mario von der Ruhr:

Kant and the Language of Reason

386

15 Ulla M. Holm:

Community, Autonomy or Both? - Feminist

Ethics Between Contextualism and Universalism

401

16 Jakob Meløe:

Remaking a Form of Life

438

Bibliography

475

Index

487 


\section{List of Contributors}

Lilli Alanen teaches philosophy at the University of Helsinki and Åbo Academy. She has published numerous articles in history of philosophy, philosophy of mind and philosophical anthropology. She is the author of Studies in Cartesian Epistemology and Philosophy of Mind (1982) and is presently finishing a book on Descartes's Concept of Mind.

Annette C. Baier is Distinguished Service Professor of Philosophy at the University of Pittsburgh. Her books include Postures of the Mind: Essays on Mind and Morals (1985); A Progress of Sentiments: Reflections on Hume's Treatise (1991) and Moral Prejudices: Essays on Ethics (1994).

Cora Diamond is Kenan Professor of Philosophy at the University of Virginia and has also taught at the University of Aberdeen and at Princeton University. She is the editor of Wittgenstein's Lectures on the Foundations of Mathematics, Cambridge, 1939. Her recent work includes The Realistic Spirit: Wittgenstein, Philosophy and the Mind, and articles on Frege and Wittgenstein, philosophy of language, ethics, and philosophy in relation to literature.

Iltham Dilman is Research Professor in Philosophy at the University of Wales, Swansea. He is the author of numerous philosophical books, including Morality and the Inner Life, A Study in Plato's Gorgias; Philosophy and the Philosophic Life, A Study in Plato's Phaedo; Quine on Ontology, Necessity and Experience; A Trilogy on Freud: Freud and Human Nature; Freud and the Moral; Freud, Insight and Change; also Mind, Brain and Behavior; Love and Human Separateness; and Existentialist Critiques of Cartesianism.

Raymond Gaita is Professor at the Institute of Advanced Research, Australian Catholic University, and at the Philosophy Department, King's College, University of London. $\mathrm{He}$ is the author of Good and Evil: An Absolute Conception, and 
numerous articles in learned journals. He has edited Value and Understanding, Essays for Peter Winch, and is presently preparing two books for publication: Humanism and Transcendence, and Remembering the Holocaust: Essays on Justice and the Sanctity of Life.

Lars Hertzberg is Professor of Philosophy at Åbo Academy, Finland. He has contributed articles to Philosophical Investigations, Inquiry, and Proceedings of the Aristotelean Society, and is the author of The Limits of Experience (1994).

Sara Heinämaa is a researcher of the Academy of Finland. She has co-written books and published articles on philosophy of mind, epistemology, cognitive science, phenomenology of the body and sexual difference.

Ulla M. Holm is Assistant Professor and Researcher in Gender Studies at the Research Council of Humanities and Social Sciences in Sweden. She writes and teaches on ethics, philosophical anthropology, feminist ethics, ethics of care and female thinkers. She is the author of Modrande och praxis, en feministfilosofisk undersökning (Mothering and Praxis: a feminist philosophical analysis, 1993).

Olli Lagerspetz is Lecturer in Philosophy at the University of Wales, Swansea. He has also taught at Abo Academy, Finland. Besides contributions to Philosophical Investigations and Philosophy, he has published philosophical and sociological articles and monographs in Swedish.

Mario von der Ruhr is Lecturer in Philosophy at the University of Wales, Swansea. He is associate editor of Philosophical Investigations, and has co-edited the volume Philosophy and the Grammar of Religious Belief.

Jakob Meløe is Professor of Philosophy Emeritus at the University of Tromsö, Norway. A native of northern Norway, he has taken an active interest in the ecology, economy, and culture of northern Norwegian coastal fishing communities. He has written numerous articles in books and journals, 
mostly in Norwegian, and mostly in the philosophy of language and the philosophy of action.

D. Z. Phillips is Rush Rhees Research Professor at the University of Wales, Swansea, and Danforth Professor of the Philosophy of Religion at the Claremont Graduate School, California. He is the author of the Concept of Prayer (1965 and 1982); Faith and Philosophical Enquiry (1970); Death and Immortality (1970); Moral Practices (with H. O. Mounce) (1970); Sense and Delusion (with Ilham Dilman, 1971); Anthronyddu am Grefydd (1974); Religion Without Explanation (1976); Through a Darkening Glass (1982); Dramau Gwenlyn Parry (1982); Belief, Change and Forms of Life (1986); R. S. Thomas: Poet of the Hidden God (1986); Faith After Foundationalism (1988 and 1995); From Fantasy to Faith (1991); Intervention in Ethics (1992); Wittgenstein and Religion (1993); Writers of Wales: J. R. Jones (1995).

Morten Raffnsøe-Møller is research fellow at the Department of Philosophy of the University of Aarhus, and studies at the New School for Social Research in New York. He has written articles on metaphysics, political philosophy and ethics, and edited books on modern metaphysics, on democracy and on architecture. He is currently working on a treatise on Nature and Human Freedom in the Light of the Ecological Crisis.

Sören Stenlund is Associate Professor of Philosophy at the University of Uppsala, Sweden. The main domain of his research is logic, philosophy of language and philosophy of mathematics. He is the author of several books and articles in these fields, including Language and Philosophical Problems.

Frederick Stoutland is Professor of Philosophy at St. Olaf College in Minnesota and Docent at the University of Helsinki. His main interests are in philosophy of action and philosophy of language. He has published a number of papers in philosophical journals and books and is finishing a book on Conceptions of Meaning and another on Truth.

Thomas Wallgren is Researcher of the Academy of Finland and associate editor of Ajatus, the yearbook of the Finnish 
Philosophical Association. He teaches at the Department of Philosophy, University of Helsinki, and has published articles on the philosophical discourse of modernity, ethics, political theory and aesthetics.

Peter Winch is Professor of Philosophy at the University of Illinois, Urbana-Champaign and emeritus professor of philosophy at the University of London. He is the author of The Idea of a Social Science and Its Relation to Philosophy; Ethics and Action; Trying to Make Sense, and Simone Weil: 'The Just Balance'. 